\title{
INFLUENCE OF THE CEREBROSPINAL FLUID LABORATORY PARAMETERS IN THE ELISA TEST FOR NEUROCYSTICERCOSIS USING A TOTAL CYSTICERCI ANTIGEN
}

\author{
Cristiane S. Casanova', Maria José S.P. Ribeiro², Reizer R. Gonçalves³, \\ Luiz Cláudio Faria", José Mauro Peralta ${ }^{5}$, Marzia Puccioni-Sohler ${ }^{6}$
}

\begin{abstract}
To evaluate if the cereb rospinal fluid (CSF) parameters may influence the cysticercosis immunoreactivity response in the CSF. CSF samples of 109 patients were analyzed and classified in three groups, according to the neurological manifestations and the reactivity in antibody-enzyme linked immunosorbent assay (Ab-ELISA) testing in CSF for neurocysticerosis (NC): group A, 18 patients with neurological disorders compatible with NC and reactive Ab-ELISA in CSF for NC; group B, 50 patients with neurological disorders non-compatible with NC and reactive Ab-ELISA for NC; group C, 41 patients with neurological disorders non-compatible with NC and non-reactive Ab-ELISA in CSF for NC. The CSF analysis in group A was compatible with NC. The group B in comparison to the groups A and C presents higher frequency and intensity of hypercytosis, presence of red blood cells in CSF, protein concentration and immunological reactive test for other etiological agents $(p \leq 0.05)$. Based on the present data, we suggest that the inflammatory process and high protein concentration may determine false positive reactions in the Ab-ELISA test for NC in the CSF.
\end{abstract}

KEY WORDS: cerebrospinal fluid, enzyme linked immunosorbent assay, neurocysticercosis.

\begin{abstract}
Influência dos parâmetros laboratoriais do líquido cefalorraquidiano no teste ELISA para neurocisticercose utilizando antígeno total de cisticerco
\end{abstract}

\begin{abstract}
RESUMO - Avaliar se os parâmetros do líquido cefalorraquidiano (LCR) podem influenciar na reatividade da resposta imune específica do LCR na neurocisticercose (NC). Amostras de LCR de 109 pacientes foram analisadas e classificadas em três grupos, de acordo com as manifestações neurológicas e reatividade do teste de Ab-ELISA para NC no LCR. Grupo A, 18 pacientes com enfermidades neurológicas compatíveis com NC e reatividade do teste Ab-ELISA para NC no LCR; grupo B, 50 pacientes com enfermidades neurológicas não compatíveis com NC e reatividade do teste Ab-ELISA para NC no LCR; grupo C, 41 pacientes com enfermidades neurológicas não compatíveis com NC e na ausência de reatividade do teste de Ab-ELISA para NC no LCR. A análise do LCR do grupo A foi compatível com NC. O grupo B apresentou maior freqüência e intensidade da pleocitose, da presença de hemácias no LCR, hiperproteinorraquia, reatividade imune para outros agentes etiológicos em comparação aos grupos $A$ e $C(p \leq 0.05)$. Os dados indicam que o processo inflamatório e os elevados níveis de concentração da proteína no LCR podem influenciar na ocorrência de reações falso positivas de Ab-ELISA para NC. Destacamos a importância da correlação clínico-laboratorial para o diagnóstico de neurocisticercose e o uso de testes laboratoriais confirmatórios.
\end{abstract}

PALAVRAS-CHAVE: líquido cefalorraquidiano, ensaio imunoenzimático, neurocisticercose.

Neurocysticercosis (NC) is a common parasitic disease of the human central nervous system (CNS) caused by Cysticercus cellulosae the larval stage of Taenia solium. The distribution of the disease is universal and constitutes an important public health problem in developing countries where sanitary conditions a re deficient. The diagnosis of NC remains difficult due to the pleomorfic and non-specific manifesta-

\footnotetext{
'Biologist, Master Science Student, Neurology Service / Gaffrèe Guinle University Hospital / Federal University of Rio de Janeiro State (HUGG/UNIRIO), Neurolife Laboratory, Rio de Janeiro RJ, Brazil; ${ }^{2}$ Biologist, Neurolife Laboratory; ${ }^{3}$ Biochemistry, Neurolife Laboratory, CSF Laboratory / Clinical Pathology Service / Clementino Fraga Filho University Hospital / Federal University of Rio de Janeiro (SPC/HUCFF/UFRJ); ${ }^{4}$ Biologist, CSF Laboratory / SPC / HUCFF / UFRJ; ${ }^{5}$ Titular-Professor, PhD, Institute of Mirobiology/UFRJ; Adjunct-Professor, PhD, CSF Laboratory / SPC / HUCFF / UFRJ; ${ }^{6}$ Ne u rology Service / HUGG / UNIRIO; Neurolife Laboratory, Rio de Janeiro/RJ. Support: FAPERJ (Fundação de Amparo á Pesquisa do Rio de Janeiro).
}

Received 25 April 2005, received in final form 22 August 2005. Accepted 5 October 2005. 
tions of the disease. Epilepsy and increased intracranial pressureare the most common neurological manifestations associated with $\mathrm{NC}^{1}$. The cerebrospinal fluid (CSF) syndrome of NC was described by Lange (1940) (apud Machado et al. ${ }^{2}$ ). It included the pre sence of pleocytosis, eosinophils, and antibodies anticysticercus for NC in CSF. In the last decades new diagnostic parameters such as the combined use of epidemiological, clinical and neuroimaging studies have been added to complement the CSF syndrome of NC. Thus, the diagnostic criteria for NC is based on the clinical and epidemiological data, neuroimaging and laboratories studies ${ }^{3,4}$.

Several immunological tests for detecting antibodies to T. solium antigens in serum and CSF have been also proposed for the laboratory diagnosis of $\mathrm{NC}^{5-8}$. However, most of them are limited in value because of poor sensitivity and/or specificity and the perfomance of the test which depends on the number, location and stage of development of the parasite ${ }^{8}$. According to published data, Ab-ELISA assay presents a lower level of sensitivity and specificity in detecting serum antibodies anti-T. solium co $\mathrm{m} p$ a red to electroimmunotransfer blot (EITB) assay, but the values increase up to $97.6 \%$ and $98.9 \%$ respectively when perf o rmed on $\mathrm{CSF}^{5,7,9}$. On the base of its sensitivity (98\%) and specificity (100\%) values, EITB assay is today considered as the best immunological test available for serum. For this reason, Del Brutto et al. ${ }^{4}$ p roposed that the presence of serum antibody antiT. solium should be considered as a major criteria but only if detected by EITB assay, while Ab-ELISA reactivity detected in the CSF should be a minor criteria (s e rum Ab-ELISA positivity is not taken into account). Nevertheless due to the lower cost and time needed to perform the test, Ab-ELISA assay is still largely perfo rmed both in serum and CSF to support the diagnosis of NC. On the other hand, the sensitivity and specificity of the test for NC may be lower according the presence of a single lesion or calcifications ${ }^{4}$. Recently studies have demonstrated false positive reactions for NC in CSF samples. This situation usually occurs in the presence of a chronic inflammatory process such as neurotuberalosis or because of cross reactivity to helminth infections, such as echinococcosis $^{10,11}$.

In this study we investigated if the CSF findings may interferer with the reactivity of Ab-ELISA testing evaluated for NC. The analysis of the albumin quotient and the $\lg G$ intrathecal fraction $\left(\operatorname{lgG}_{\mathrm{IF}}\right)$ were also included to study the blood-CSF barrier function and the intrathecal synthesis of IgG, respectively ${ }^{12}$.

\section{METHOD}

Population - We selected 109 cases among patients under laboratory investigation in a reference CSF Laboratory in Rio de Janeiro city (Neurolife Laboratory) and in CSF Laboratory of the Clinical Pathology Service of the Clementino Fraga Filho University Hospital of the Federal University of Rio de Janeiro (HUCFF/UFRJ), during the period between January 1999 and May 2002. The study received approval of the Hospital Ethical Comitee Board. After the diagnostic hypothesis was established, according Sotelo et al. ${ }^{3}$, the patients were classified in three groups:

G roup A - 18 patients with diagnosis of established NC based on the presence of neurological manifestations compatible with NCand reactive Ab-ELISA for NC in $\mathrm{CSF}^{3,13}$;

Group B - 50 patients with neurological diseases noncompatible with NC and reactive Ab-ELISA for NC in CSF: Guillain Barrè syndrome (four patients), chronic inflammatory demyelinating polyradiculoneuropathy (t en patients), viral meningitis (five patients), bacterial meningitis (22 patients), stroke (four patients), cerebral tumor (five patients) $)^{3,11,13}$;

Group C - 41 patients with neurological diseases noncompatible with NC and non-reactive Ab-ELISA for NC in CSF: multiple sclerosis (four patients), chronic inflammatory demyelinating polyradiculoneuropathy (29 patients) and cerebral tumor (eight patients) ${ }^{13,14}$.

CSF analysis - CSF specimens were evaluated for white and red blood cell counts, protein and glucose concentration and reactivity for HIV, HTLV-I/II, cytomegalovirus (CMV), Herpes simplexvirus (HSV) and Toxoplasma gondii using Ab-ELISA commercial kits for antibodies detection. Presence of bacteria and fungi was evaluated by conventional methods for culture isolation and identification. Antibodies to Taenia solium antigens were detected using BioELISA neurocisti kit (BioMérieux Brasil S.A., RJ, Brazil) following the manufacturer instructions. Ab-ELISA relative index for NC was determined by dividing the optical density (OD) re ading obtained for the sample testing by the cut-off OD value. CSF and corresponding serum samples were analyzed for total IgG and albumin by nephelometry (Dade Behring, Inc., Marburg GmbH, Germany). The evaluation of CSF locally synthesized immunoglobulin was based on the $\operatorname{IgG}_{\mathrm{IF}}$ according to Reiber and Felgenhauer ${ }^{12}$. Blood-CSF barrier dysfunction was determined by using the albumin quotient $^{12}$.

Data analysis - The Mann-Whitney statistical method was used to compare the quantitative data and the test of Fisher or chi-square for the proportions; $p$ values $<0.05$ were considered statistically significant.

The receiver operator characteristic (ROC) curve com pares the relationship between the sensibility and specificity of the CSF parameters for the groups A and B (by the Graphical Methods for Data Analysis). The ROC curve analysis was selected to find the best cutpoint for the CSF parameters in sense of to differentiate the groups $A$ and $B$. The sensitivity ( $\%$ true-positive) and specificity (\% false-positive) for each parameter was calculated and compared with the diagnosis criteria. 


\section{RESULTS}

The median and the standard deviation of the age in the groups $A, B$ and $C$ were $40.83 \pm 18.26,44.72 \pm$ 21.84 and $32.68 \pm 16.26$ yrs., respectively. The most frequent clinical manifestations of the patients from group A (NC) are shown in Table 1.

Significant differences in the CSF parameters were found in the laboratory analysis among the three studied groups (Table 2). In group A, most of CSF samples presented laboratory findings compatible with NC, such as mild pleocytosis with a predominance of lymphocytes and monocytes associated with eosinophils (11\%) and hyperproteinorrachia. A significant number of patients $(60 \%)$ had intrathecal synthesis of total IgG. All had antibodies anti-cysticercus of $T$. solium in CSF by ELISA. The presence of pleocytosis, eosinophils and antibodies anti-cysticercus represents the classical syndrome of NC (Table 2). Group B presented a high number of patients with intense pleocytosis, presence of red blood cells, higher concentration of protein and CSF-blood barrier dysfunction in comparison with samples from groups $A$ and C. CSF samples composing group $C$ were normal, except for a discrete pleocytosis and the presence of erythrocytes in two patients. All CSF samples in this group had negative results when tested for antibodies to NC by ELISA (Table 2).
No difference was found in the distribution of the ELISA relative index between samples from groups $A$ and $B$ (Fig 1).

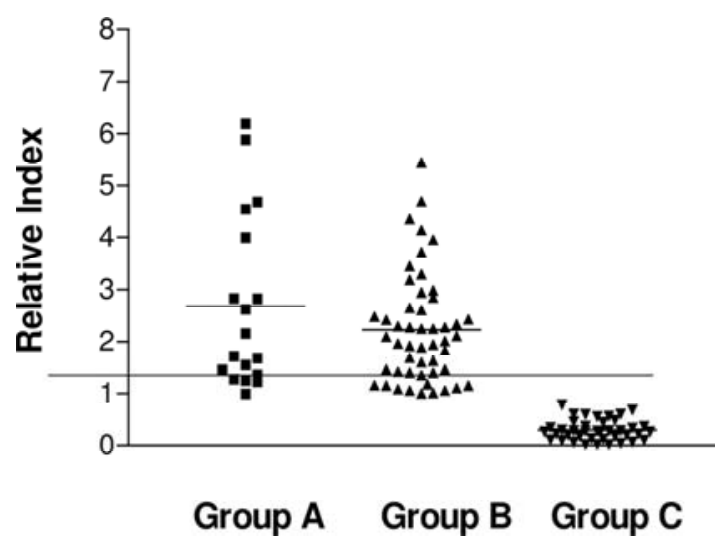

Fig 1. Results of Ab-ELISA testing (using T. solium antigens) in CSF samples, expressed as in relative index (sample optical den sitylcut-off optical density values), obtained from the three $g$ roups of patients with neurological manifestations ( $A-N C$ patients with positive ELISA test for NC in CSF, B - neurologi cal diseases non-compatible with NC with positive ELISA test for NC in CSF and C - neurological diseases non-compatible with NC with negative ELISA test for NC in CSF).

Table 1. Clinical manifestations, relation of active and inactive forms of NC in group $A,(n=18)$.

\begin{tabular}{lcccc}
\hline \multicolumn{2}{l}{ Clinical manifestations } & \multicolumn{2}{c}{ Active forms } & Inactive forms \\
Headache & Seizures & Cysts & Hydrocephalus & Calcifications \\
\hline (8) $28 \%$ & (10) $72 \%$ & (6) $33 \%$ & (2) $11 \%$ & (10) $56 \%$ \\
\hline
\end{tabular}

Table 2. Results of laboratory analysis of CSF samples from patients with neurological manifestations and positive (groups $A$ and $B$ ) or negative (group $C$ ) results in ELISA test ing for neurocysticercosis in CSF.

\begin{tabular}{lcccccc}
\hline & \multicolumn{3}{c}{ Groups of CSF samples } & \multicolumn{3}{c}{ Statistical analysis } \\
Laboratory & A & B & C & AxB & AxC & BxC \\
Findings & $\mathrm{n}=18$ & $\mathrm{n}=50$ & $\mathrm{n}=41$ & $\mathrm{p}$ value & p value & p value \\
\hline Pleocytosis $>4 / \mathrm{mm}^{3}$ & $33 \%$ & $66 \%$ & $5 \%$ & $<0.05$ & $<0.05$ & - \\
Erythrocytes $>0 / \mathrm{mm}^{3}$ & $44 \%$ & $68 \%$ & $58 \%$ & $<0.05$ & $>0.05$ & $>0.05$ \\
Protein $=>40 \mathrm{mg} / \mathrm{dL}$ & $55 \%$ & $88 \%$ & $0 \%$ & $<0.05$ & $<0.05$ & $<0.05$ \\
(IgGIF) $>10 \%$ & $60 \%$ & $27 \%$ & $0 \%$ & $>0,05$ & $<0.05$ & $<0.05$ \\
Q. Albumin $>7 \times 10^{-3}$ & $33 \%$ & $73 \%$ & $0 \%$ & $<0.05$ & - & - \\
R.E.T. Cysticercosis & $100 \%$ & $100 \%$ & $0 \%$ & - & - & - \\
\hline
\end{tabular}

R.E.T., (reactive ELISA test) for cysticercosis in $\mathrm{CSF}_{\text {; }} \mathrm{IgG}_{\mathrm{IF}}$ (intrathecal fraction of igG) $>10 \%$ indicates intrathecal synthesis of IgG; Q. Albumin $>7 \times 10^{-3}$ indicates blood-CSF barrier dysfunction. 


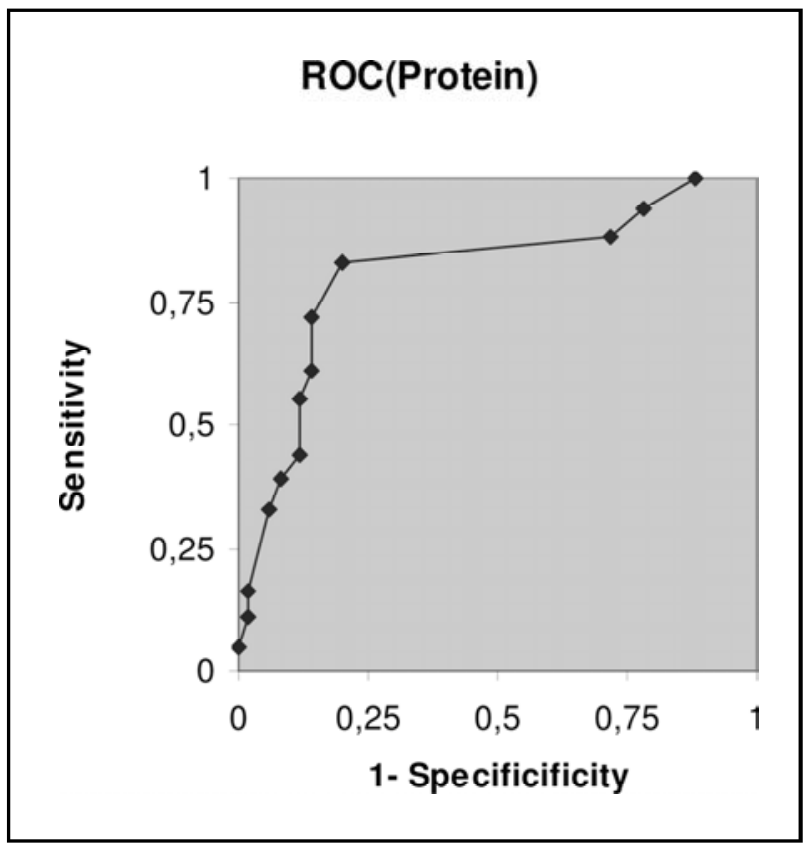

Fig 2. ROC (receiver operator characteristic curve) showing the correlation between sensitivity and specificity for protein con centration in the CSF for the neurocysticercosis diagnosis. The cuttpoint represent the degree of diagnostic certainty.

The ROC curve (Fig 2) shows the best cutpoint for the protein concentration in the group $A$ (patients with the diagnosis of NC). The best cutpoint for the $p$ rotein concentration was $\leq 60 \mathrm{mg} / \mathrm{dL}$, with a sensitivity of $83 \%$ and a specificity of $80 \%$. The best cutpoint for pleocytosis was $\leq 7$ cells $/ \mathrm{mm}^{3}$, with a sensitivity of $77.8 \%$ and specificity of $64 \%$. A cutpoint was not found for the other CSF parameters in the group $A$ and $B$.

\section{DISCUSSION}

Assuming that patients enrolled in group $A$ are the true positive (patients affected by NC) and group $C$ the true negative, the problem with false results arises from the patients enrolled in group B (patients with neurological disorders not compatible with NC and $A b$-ELISA reactivity for NC in CSF).

Significant diffe rences were found among the CSF parameters in the NC group (group A) and the control groups (groups B and C). It included: protein concentration, pleocytosis, albumin quotient and the presence of ery th rocytes. The high concentration of protein associated with the blood-CSF barrier dysfunction among CSF samples included in group $B$ indicated that part of this protein was not synthesized in the $\mathrm{CNS}^{15}$. False-positive results for Ab-ELISA testing in serum have been detected probably due to the serum proteins that bind to cysticercus $T$. soliumanti- gens ${ }^{5,16}$. Glycoproteins of $T$. solium have been considered as very sensitive and specific antigens for NC diagnosis when western blot (WB) assay is used with serum samples but they did not show the same efficiency on Ab-ELISA testing ${ }^{5}$. The occurrence of false-positive reactions in Ab-ELISA CSF test may be related to blood-CSF barrier dysfunction allowing the passage of serum antibodies and other proteins to the CNS.

In the group B, elevated pleocytosis associated with other infectious disease agents (viral and bacterial) indicated meningeal inflammatory process not related with NC. In this group all CSF samples were reactive in the Ab-ELISA for NC but without clinical and imaging findings for NC. Another explanation of false positive Ab-ELISA test for NC could be associated to cross reactivity to other infectious agents ${ }^{11}$. This hypothesis was not acceptable because the patients in this group presented different kinds of diseases: infectious (viral and bacterial meningitis) but also non-infectious (stroke, tumor and polineuropathy).

We used the ROC curve to compare the sensitivity and specificity of the CSF parameters for the groups $A(N C)$ and $B$ (false-positive for NC), in sense of to choose a best cut-point. Based on our findings, it was demonstrated a greater probability of CSF false-positive reactions in Ab-ELISA test for NC (using $T$. soli um antigens) in the cases of pleocytosis higher than 7 cells $/ \mathrm{mm}^{3}$ or protein concentration in CSF higher than $60 \mathrm{mg} / \mathrm{dL}$.

Several studies have been conducted in order to improve the diagnosis of $\mathrm{NC}^{2,6}$. Analysis of the integrity of the blood-CSF barrier function has contributed to determine the intrathecal synthesis of antibody. In addition, purified larval Taenia antigens from homologous ( $T$. solium) or heterologous ( $T$. crassiceps) parasites have been obtained and characterized in order to obtain reagents with high degree of specificity $^{6,17-19}$. Antigen preparations with contamination of pig proteins, a common problem when $T$. solium cysts are used, are avoided using antigens obtained from larvae of $T$. crassiceps $^{2,19,20}$.

As a retrospective study, we had some limitations, such as the absence of paired serum samples to compare the specific serum and CSF antibodies. However, the Ab-ELISA assay (using $T$. solium antigens) in serum is not a good test for the diagnosis of NC, due the presence of high frequency of false-positive reactions. We used the Sotelo's criteria for the diagnosis of NC, considering it more appropriate for the kind of study. It is based predominantly on clinical and imaging features ${ }^{1}$. 
Here, we demonstrated that the CSF findings may influence the immunoreactivity of the CSF ELISA test for NC. CSF reactive patients without NC had higher frequency of blood-CSF dysfunction, elevated level of protein concentration, pleocytosis and red blood cells count in comparison to the CSF reactive patients with NC (true positive). The most frequently findings were the high level of protein and blood-CSF barrier dysfunction. These may contribute to the serum p roteins that bind to cysticercus $T$. soliumantigens ${ }^{5}$ passage to the CSF, conducting to false positive reaction. In addition, we also proposed a cut-point for the protein concentration and pleocytosis. The chance of false-positive Ab-ELISA for NC increases with the concentration of protein higher than $60 \mathrm{mg} / \mathrm{dL}$ (sensitivity of $83 \%$ and a specificity of $80 \%$ ) and pleocytosis higher than 7 cells $/ \mathrm{mm}^{3}$ (sensitivity of $77.8 \%$ and specificity of $64 \%$ ). Thus, the results of the Ab-ELISA tests should be carefully considered in together with other clinical, laboratorial and epidemiological data for the diagnosis of NC. Confirmatory tests for CSF should be included in the routine diagnosis criteria for NC.

Acknowledgments - The authors thank Mrs. Rosângela Noé from "Comissão de Investigação Científica do HUCFF/ UFRJ"for the statistical analysis of this study.

\section{REFERENCES}

1. Sotelo J, Del Butto OH. Review of neurocysticercosis. Neuro s u rgFocus 2002;12:1-7.

2. Machado LR, Livramento JA, Vaz AJ, et al. IgG intrathecal synthesis and specific antibodies index in patients with neurocysticercosis. Arq Neuropsiquiatr 2002;60:395-399.

3. Sotelo J, Guerrero V, Rubio F. Neurocysticercosis: a new classification base on active and inactive forms. Arch Intern Med 1985;145:442-445.

4. Del Brutto OH, Rajsherkhar V, White ACJr, et al. Proposed diagnostic criteria for neurocysticercosis. Neurology 2001;57:177-183.

5. Tsang VCW, Brand JA, Boyer AE. An enzyme-linked immoelectrotrans- fer blot assay glycoprotein antigens for diagnosing human cysticercosis. J Infec Dis 1989;159:50-59.

6. Ito A, Plancarte A, Ma L, et al. Novel antigens for neurocysticercosis: simple method for preparation and evaluation for serodiagnosis. Am J Trop Med Hyg 1998;59:291-294.

7. P roaño-Narvez JV, Meza-Lucas A, Mata-Ruiz O, Garcia-Jeronimo RC, Cor reaD. Laboratory diagnosis of human neurocysticercosis: doubleblind comparison of enzyme-linked immunosorbent assay and electroimmunotransfer blot assay. J Clin Microbiol 2002;40:2115-2118.

8. Dorny P, Brandt J, Zoli A, Geerts S. Serodiagnostic tools for human and porcine cysticercosis. Acta Trop 2003;87:79-86.

9. Vaz AJ, Livramento JA. Neurocisticercose. In Ferreira AW, Avila SLM (eds). Diagnóstico laboratorial das principais doenças infecciosas, 2.Ed. Rio de Janeiro: Guanabara Koogan, 2001:316-322.

10. Katti MK. Assessement of antibody responses to antigens of Mycobac terium tuberculosis and Cysticeras cellulosae in cere b rospinal fluid of chronic meningitis patients for definitive diagnosis as TBM/NCC by passive hemmaglutination and immunoblot assays. FEMS Immnol Med Microbiol 2002;33:57-61.

11. Gekeler F, Einchenlaub S, Mendonza EG, Sotelo J, Hoelscher M, Hoschen T. Sensitivity and specificity of ELISA and immunoblot for diagnosing neurocysticercosis. Eur J Clin Microbiol Infec Dis 2002; 21:227-229.

12. Reiber H, Felgenhauer K. Protein transfer at the blood cereb rospinal fluid barrier and the quantification of the humoral immune response within the central nervous system. Clin Chem 1987;163:319-328.

13. Adams RD, Victor M, Ropper AH. Principles of neurology. International Edition New York: MC Graw-Hill, 2001.

14. Mc Donald WI, Compston A, Edan G, et al. Recommended diagnostic criteria for multiple sclerosis: guidelines from the international panel on the diagnosis of multiple sclerosis. Ann Neurol 2001;50:121-127.

15. Reiber H, Peter JB. Cereb rospinal fluid analysis: disease-related patterns and evaluation programs. J Neurol Sci 2001;184:101-122.

16. Vaz AJ, Ferreira AW, Silva MV, et al. Teste imunoenzimático para pesquisa de anticorpos anti-Cysticercus cellulosae em líquidos cefalorraquianos de pacientes com meningites de etiologia indeterminada. Rev Inst Med Trop Med São Paulo 1990;32:196-203.

17. Peralta RH, Vaz AJ, Pardini A, et al. Evaluation of an antigen from Taenia crassiceps cysticeraus for the serodiagnosis of neurocysticercosis. Act Trop 2002;83:159-168.

18. P a rdini AX, Peralta $\mathrm{RH}, \mathrm{Vaz} \mathrm{AJ}$ et al. Use of Taenia crassiceps cysticercus antigen preparations for detection of antibodies in cerebrospinal fluid simples from patients with neurocysticercosis. Clin Diag Immunol 2002;9:190-193.

19. Larralde C, Sotelo J, Montoya RM, et al. Immunodiagnosis of human cysticercosis in cerebrospinal fluid: antigens from from murine Taenia crasssiceps cysticeri effectively substitute those from porcine Taenia soli um. Arch Pathol Lab Med 1990;114:926-928.

20. Bueno EC, Vaz AJ, Machado LR, Livramento JA, Mielle SR. Specific Taenia crassiceps and Taenia solium antigenic peptides of neurocysticercosis immunodiagnosis using serum samples. J Clin Microbiol 2000; 38:146-151. 